\section{Sweet Corn Crop Nitrogen Status Evaluation by Stalk Testing}

\author{
Joseph R. Heckman ${ }^{1}$ \\ Plant Biology and Pathology Department, Rutgers University, 59 Dudley \\ Road, New Brunswick, NJ 08901-8520
}

\author{
Ray Samulis ${ }^{2}$ \\ Rutgers Cooperative Extension of Burlington County, P.O. Box 6000, Mount \\ Holly, NJ 08060-1317
}

\begin{abstract}
Peter Nitzsche ${ }^{2}$
Rutgers Cooperative Extension of Morris County, P.O. Box 900 Court House, Morristown, NJ 07963-0900
\end{abstract}

\section{Additional index words. Zea mays, PSNT}

\begin{abstract}
Sweet corn (Zea mays L.) growers evaluating new practices for $\mathbf{N}$ management, such as the presidedress soil nitrate test (PSNT), are interested in relating observations about crop performance at time of harvest to their $\mathbf{N}$ fertility program. For this purpose, the concentration of nitrogen $(N)$ in the lower portion of sweet corn stalks was examined on the day of harvest as a basis for evaluating the crop $\mathbf{N}$ status. Sweet corn stalk tissue was collected from N-rate experiments by cutting a stalk section at 15 and $35 \mathrm{~cm}$ aboveground and removing leaf material from the resulting $20-\mathrm{cm}$ segment. Samples were dried and analyzed for total Kjeldahl $\mathbf{N}$. Relationships between crop yield and stalk $\mathbf{N}$ concentration indicated that concentrations $<\mathbf{1 1} \mathbf{~ g} \cdot \mathrm{kg}^{-1}$ are $\mathrm{N}$ deficient and underfertilized; $\mathrm{N}$ concentrations between 11 and $16.5 \mathrm{~g} \cdot \mathrm{kg}^{-1}$ are marginally deficient; and between 16.5 and $21 \mathrm{~g} \cdot \mathrm{kg}^{-1}$ the $\mathrm{N}$ status is optimum. Concentrations of $\mathrm{N}>21 \mathrm{~g} \cdot \mathrm{kg}^{-1}$ are above optimum and indicate that sweet corn was overfertilized with $\mathrm{N}$. When soil nitrate concentrations (PSNT $>25 \mathrm{mg}$ $\mathrm{NO}_{3}-\mathrm{N}$ per kilogram) indicated sufficient $\mathrm{N}$ at time of sidedressing, stalk $\mathrm{N}$ concentrations generally indicated $\mathrm{N}$ sufficiency at harvest.
\end{abstract}

Plant and soil tests provide key information for nutrient management planning that serves to minimize environmental impact and maintains the economic viability of crop production. The presidedress soil nitrate test (PSNT) and end-of-season stalk $\mathrm{N}$ test are testing procedures that were originally developed to improve $\mathrm{N}$ fertility management for field corn production (Binford et al., 1990; Magdoff, 1991). Use of the PSNT has already been successfully extended to sweet corn (Heckman et al., 1995) and other vegetable crops (Hartz et al., 2000; Heckman et al., 2002). The development of a stalk $\mathrm{N}$ testing technique for sweet corn could direct growers to improved $\mathrm{N}$ management as it has for field corn (Hooker and Morris, 1999; Sims et al., 1995).

Sweet corn growers evaluating levels of $\mathrm{N}$ application or new $\mathrm{N}$ management practices, such as the PSNT, may be particularly inter-

\footnotetext{
The research reported in this publication was supported by the New Jersey Agricultural Experiment Station and the Northeast Region Sustainable Agriculture Research and Education Program. Use of trade names does not imply endorsement of the products named nor criticism of similar ones not named. We appreciate the technical assistance of Dennis Haines, Scott Hall, Kim Mayer, and Wendy Hill.

${ }^{1}$ Extension Specialist in Soil Fertility; to whom reprint requests should be addressed. E-mail address: heckman@aesop.rutgers.edu

${ }^{2}$ County Agricultural Agent.
}

ested in whether their $\mathrm{N}$ fertility program was appropriate. This fits the function of the stalk $\mathrm{N}$ test, which in the case of field corn, can validate the current $\mathrm{N}$ fertility program or can determine if the $\mathrm{N}$ application was insufficient or excessive. Collecting stalk samples at time of sweet corn harvest should allow observations about current crop performance to be related to the sufficiency of the $\mathrm{N}$ fertility program. Furthermore, this should allow growers to learn from that experience, and to direct efforts to improve $\mathrm{N}$ management in future growing seasons.

Corn stalk $\mathrm{N}$ testing is based on the assumption that "nitrate $\left(\mathrm{NO}_{3}^{-}\right)$tends to accumulate in the lower portion of mature corn stalks when abundant amounts of $\mathrm{N}$ are available in soils" (Binford et al., 1990; Hanway and Englehorn, 1958; Hoffer, 1926). Sweet corn, which is harvested at a physiologically immature growth stage, may behave differently than field corn with respect to $\mathrm{NO}_{3}-\mathrm{N}$ accumulations in stalk tissue. A recent study by Hooker and Morris (1999), however, showed that stalk $\mathrm{NO}_{3}-\mathrm{N}$ testing was an effective method of defining excess $\mathrm{N}$ availability to silage corn, which is harvested about 3 weeks before physiological maturity. In very young corn plants (4 weeks after emergence) stalk $\mathrm{NO}_{3}-\mathrm{N}$ was, however, found to be a poor predictor of soil $\mathrm{N}$ availability as a result of the sensitivity of stalk $\mathrm{NO}_{3}-\mathrm{N}$ concentrations at this early growth stage to the influence of solar radiation (Iversen et al., 1985) and soil moisture availability (Fox et al., 1989). Because sweet corn is generally irrigated, the effect of soil moisture on stalk $\mathrm{NO}_{3}-\mathrm{N}$ concentration may be less of a factor than for field corn. Stalk total Kjeldahl N (TKN) may be a better indicator of sweet corn $\mathrm{N}$ status because it measures both $\mathrm{NO}_{3}-\mathrm{N}$ and reduced-N in the stalk tissue, and it may minimize the importance of solar radiation on $\mathrm{NO}_{3}$ reduction.

This study was conducted to evaluate stalk $\mathrm{N}$ testing as a means to determine if the $\mathrm{N}$ management program used for sweet corn provided insufficient, optimum, or excessive plant-available N. Stalk N testing was evaluated both by measuring TKN and $\mathrm{NO}_{3}-\mathrm{N}$ concentrations. The relationship between the PSNT and stalk $\mathrm{N}$ test results was examined. The results of stalk $\mathrm{N}$ testing both from sweet corn cultivar trials and a survey of commercial sweet corn fields are also reported.

\section{Materials and Methods}

This study used 24 of the $61 \mathrm{~N}$-response trials that were conducted in New Jersey from 1991 to 1994 to calibrate the PSNT for sweet corn (Heckman et al., 1995). At planting, starter fertilizer was applied with $\mathrm{N}$ at 22 $\mathrm{kg} \cdot \mathrm{ha}^{-1}$, and additional $\mathrm{N}$ was sidedressed at 0 , $45,90,135$, and $180 \mathrm{~kg} \cdot \mathrm{ha}^{-1}$. The PSNT soil sampling was performed when plants were 30 $\mathrm{cm}$ tall at the whorl by collecting eight cores ( 2 $\mathrm{cm}$ in diameter $\times 30 \mathrm{~cm}$ deep) between the rows of each control plot. Harvesting procedures were as previously described (Heckman et al., 1995). Two additional trials were conducted in 1996 using the above methods. Irrigation was applied at all sites as needed to avoid drought stress.

Stalk samples were collected from the sweet corn $\mathrm{N}$ response trials using procedures similar to those for field corn (Binford et al., 1990) except that in this study the stalk samples were collected on the day of harvest for sweet corn. The 20-cm segments were collected by cutting the stalk at 15 and $35 \mathrm{~cm}$ aboveground from 10 randomly selected plants within the two center rows of six row plots. All leaf tissues were removed from the stalk samples. The samples were dried at $70^{\circ} \mathrm{C}$ and ground in a Wiley mill to pass a 1-mm screen. Stalk $\mathrm{NO}_{3}-\mathrm{N}$ concentrations were determined by extraction with 2 M KCL (1:10, w:v) and analyzed for $\mathrm{NO}_{3}-\mathrm{N}$ colorimetrically using a Technicon Autoanalyzer (Technicon, Tarrytown, N.Y.). Total Kjeldahl $\mathrm{N}$ was determined by using the permanganate-reduced $\mathrm{Fe}$ method to include $\mathrm{NO}_{3}-\mathrm{N}$ (Bremner and Mulvaney, 1982).

The Rutgers integrated crop management program began conducting the stalk $\mathrm{N}$ test for commercial sweet corn growers in 1997. Between 1997 and 1999, stalk samples were collected from 55 fields and the data were summarized as a survey of the $\mathrm{N}$ status of New Jersey sweet corn acreage. In addition to the sweet corn $\mathrm{N}$ response trials, stalk samples were also collected from cultivar trials that were conducted during 1998 to 2000. The cultivar trials were conducted using a randomized complete-block design with four replications. They were established with a population 
of 64,000 plants/ha and uniformly fertilized with $\mathrm{N}$ at $180 \mathrm{~kg} \cdot \mathrm{ha}^{-1}$. The cultivars Calico Belle, Brilliance Film Coat, Sensor, and Silverado were sampled for stalk $\mathrm{N}$ testing each year at time of harvest. Concentrations of TKN and $\mathrm{NO}_{3}-\mathrm{N}$ in stalk samples were compared among cultivars by ANOVA.

Relative yields were calculated as the yield of marketable ears produced with $\mathrm{N}$ at 0,45 , 90 , or $135 \mathrm{~kg} \cdot \mathrm{ha}^{-1}$ sidedress $\mathrm{N}$, expressed as a percentage of the yield observed for $\mathrm{N}$ at the $180 \mathrm{~kg} \cdot \mathrm{ha}^{-1}$ rate of applied sidedress N. The relationship between stalk TKN or $\mathrm{NO}_{3}-\mathrm{N}$ concentration and relative yield was examined using Cate-Nelson analysis (Cate and Nelson, 1965 ) by partitioning data into N-responsive and nonresponsive $\mathrm{N}$ rates. Setting the horizontal line at an acceptable relative yield level of $92 \%$ modified this procedure. The vertical line drawn according to Cate-Nelson analysis was used to determine the critical stalk TKN and $\mathrm{NO}_{3}-\mathrm{N}$ concentration, which effectively establishes the lower value of the optimal range. The relationships between the PSNT $\mathrm{NO}_{3}-\mathrm{N}$ concentration and the stalk TKN or $\mathrm{NO}_{3}-\mathrm{N}$ concentration were also examined by Cate-Nelson analysis.

\section{Results and Discussion}

The relationships between relative yield and stalk $\mathrm{TKN}$ or $\mathrm{NO}_{3}-\mathrm{N}$ concentration (Fig. 1 $a$ and $b$ ) suggest that stalk testing for sweet corn at time of crop harvest is useful for diagnostic purposes. Clearly, very low concentrations of TKN or $\mathrm{NO}_{3}-\mathrm{N}$ in stalk tissue are associated with low relative yields and very high concentrations are associated with near maximum yield. Cate-Nelson graphic analysis for the database using $\mathrm{TKN}$ or $\mathrm{NO}_{3}-\mathrm{N}$ results in critical levels of TKN at $16.5 \mathrm{~g} \cdot \mathrm{kg}^{-1}$ or $\mathrm{NO}_{3}-\mathrm{N}$ at $11 \mathrm{~g} \cdot \mathrm{kg}^{-1}$. We selected these critical levels to minimize the number of outliers but also to ensure that not more than 5\% of the errors would fall into the lower right quadrant. This balance of errors is similar to that used by Fox et al. (2001) to ensure acceptability of the test to growers who have a low tolerance of incorrect predictions of $\mathrm{N}$ sufficiency when, in fact, $\mathrm{N}$ supply was deficient. There were nearly the same number of errors in the upper left quadrant for the stalk test measured as TKN (11.7\%) as for $\mathrm{NO}_{3}-\mathrm{N}$ $(13.0 \%)$. Error rates suggest that stalk testing using TKN concentrations may be better at predicting sweet corn $\mathrm{N}$ sufficiency than $\mathrm{NO}_{3}$ N.

The linear correlation between stalk TKN concentrations and stalk $\mathrm{NO}_{3}-\mathrm{N}$ concentrations had an $\mathrm{r}^{2}$ of 0.67 , and the regression equation was:

$$
\mathrm{NO}_{3}-\mathrm{N}=0.65 \mathrm{TKN}-1.6
$$

This equation indicates that as stalk tissue TKN concentration increases, an increasing percentage of this tissue $\mathrm{N}$ is present in the form of $\mathrm{NO}_{3}-\mathrm{N}$. The critical levels for stalk $\mathrm{NO}_{3}-\mathrm{N}$ concentration established by Binford et al. (1990) for field corn was $0.25 \mathrm{~g} \cdot \mathrm{kg}^{-1}$, and by Hooker and Morris for silage corn was 0.5 $\mathrm{g} \cdot \mathrm{kg}^{-1}$. These values are substantially lower
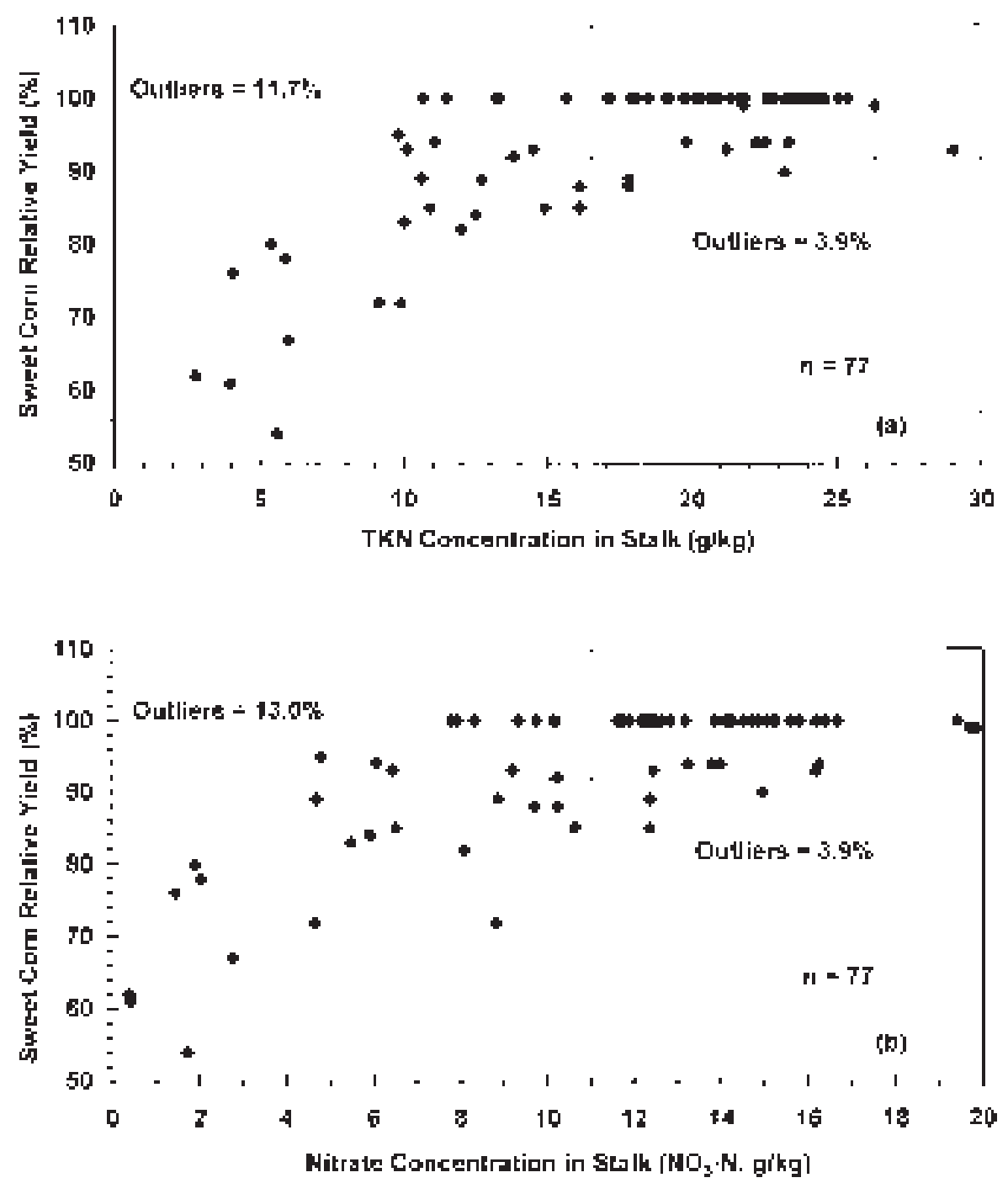

Fig. 1. Relationship between at-harvest stalk total Kjeldahal $\mathrm{N}\left(\right.$ a) or $\mathrm{NO}_{3}-\mathrm{N}(\mathbf{b})$ concentrations and relative yield of sweet corn.

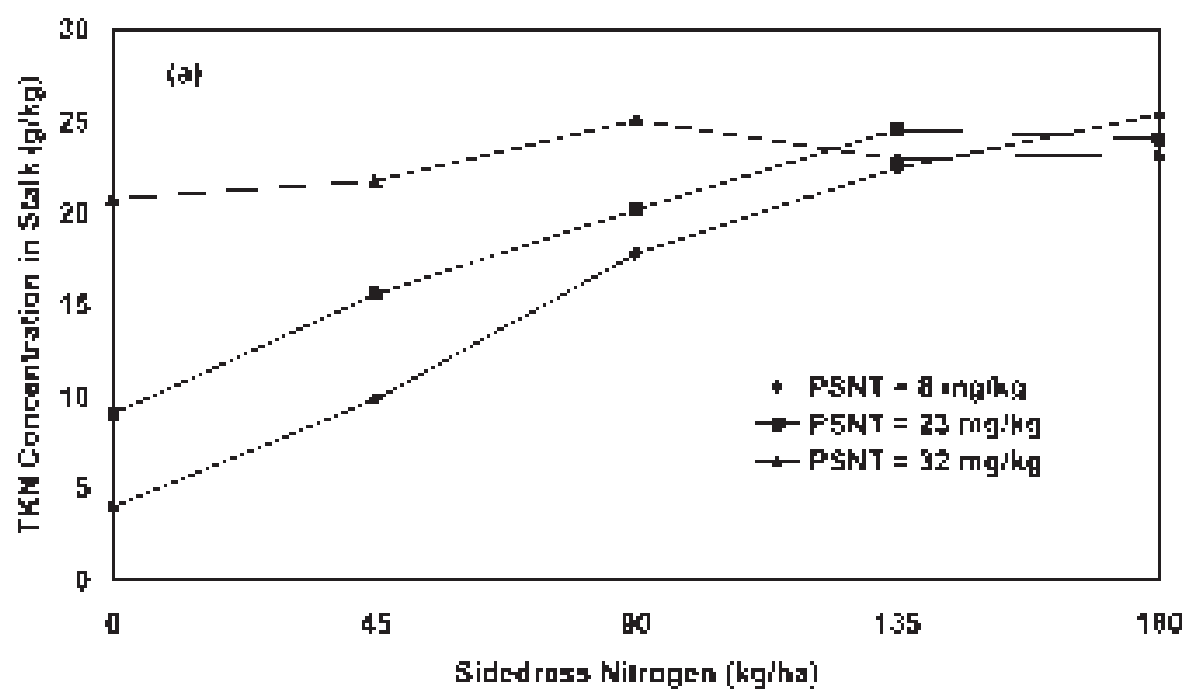

Fig. 2. Concentrations of total Kjeldahal $\mathrm{N}$ (TKN) in sweet corn stalk tissue at harvest in response to $\mathrm{N}$ fertilizer rate at three field sites with different PSNT levels. 
than the $\mathrm{NO}_{3}-\mathrm{N}$ at $11 \mathrm{~g} \cdot \mathrm{kg}^{-1}$ critical level that was established in our study for sweet corn sampled at time of fresh harvest. The magnitude of this difference is probably largely a result of field corn harvest occurring at a much later physiological growth stage such that much of the $\mathrm{NO}_{3}-\mathrm{N}$ stored in the lower stalk tissue has been remobilized for grain fill. Because sweet corn harvest and stalk sampling occurs at an earlier physiological growth stage than even silage, remobilization of stalk $\mathrm{NO}_{3}-\mathrm{N}$ is apparently limited for sweet corn. This may account for the higher error rate found for sweet corn stalk $\mathrm{NO}_{3}-\mathrm{N}$ critical levels as compared to the stalk TKN test or the lower error rates of the field corn stalk $\mathrm{NO}_{3}-\mathrm{N}$ test (Fox et al., 2001).

Sweet corn stalk tissue TKN concentrations increase with $\mathrm{N}$ fertilizer rate, but this is also influenced by the level of $\mathrm{NO}_{3}-\mathrm{N}$ available in soil as measured by the PSNT (Fig. 2). A Cate-Nelson graphical analysis of the relationship between PSNT soil $\mathrm{NO}_{3}-\mathrm{N}$ concentrations and stalk TKN concentrations show that most of the 24 field sites were partitioned into two quadrants (Fig. 3). Data points in the lower left quadrant represent field sites that test below the PSNT critical level of $\mathrm{NO}_{3}-\mathrm{N}$ at $25 \mathrm{mg} \cdot \mathrm{kg}^{-1}$ (Heckman et al., 1995) at the appropriate time for sidedressing, but when not given sidedress $\mathrm{N}$, result in stalk samples collected at harvest time that indicate $\mathrm{N}$ deficiency. Data points in the upper right quadrant represent field sites that test above the PSNT critical level of $25 \mathrm{mg} \mathrm{NO}_{3}-\mathrm{N}$ in soil and, when not given sidedress $\mathrm{N}$, result in stalk samples collected at harvest that test primarily above the critical level of TKN at $16.5 \mathrm{~g} \cdot \mathrm{kg}^{-1}$ (established in Fig. 1). Overall there is good agreement between sufficiency predictions as indicated by the PSNT and by stalk TKN testing.

The difficulty with attempts to establish a critical stalk TKN concentration is that the transition between deficiency and sufficiency is not sharply defined. Sweet corn cultivar differences in stalk TKN or $\mathrm{NO}_{3}$-N concentration may partially account for this (Table 1). In sweet corn cultivar trials conducted over a 3year period, the cultivar Sensor had significantly lower stalk TKN and $\mathrm{NO}_{3}$-N concentrations than the other three cultivars.

Based on the current study findings, we propose the interpretations as listed in Table 2 for stalk $\mathrm{N}$ testing in sweet corn. Although interpretations are provided for both TKN and $\mathrm{NO}_{3}-\mathrm{N}$ concentrations, $\mathrm{TKN}$ is the preferred measurement because it made fewer incorrect predictions about sweet corn $\mathrm{N}$ status.

The usefulness of stalk $N$ testing was shown by the results of stalk samples collected on the day of harvest from 55 commercial sweet corn fields in New Jersey during the summers of 1997 to 1999 . Stalk TKN concentrations ranged from 6 to $37 \mathrm{~g} \cdot \mathrm{kg}^{-1}$. Both the mean and median stalk TKN concentrations were $19 \mathrm{~g} \cdot \mathrm{kg}^{-1}$. Based on the interpretations in Table $1,18 \%$ of the samples would be classified as $\mathrm{N}$ deficient, $16 \%$ as marginal, $31 \%$ as optimal and $35 \%$ as excessive in $\mathrm{N}$ status. Providing this information to sweet corn producers enables them to make adjustments in their $\mathrm{N}$ fertility program

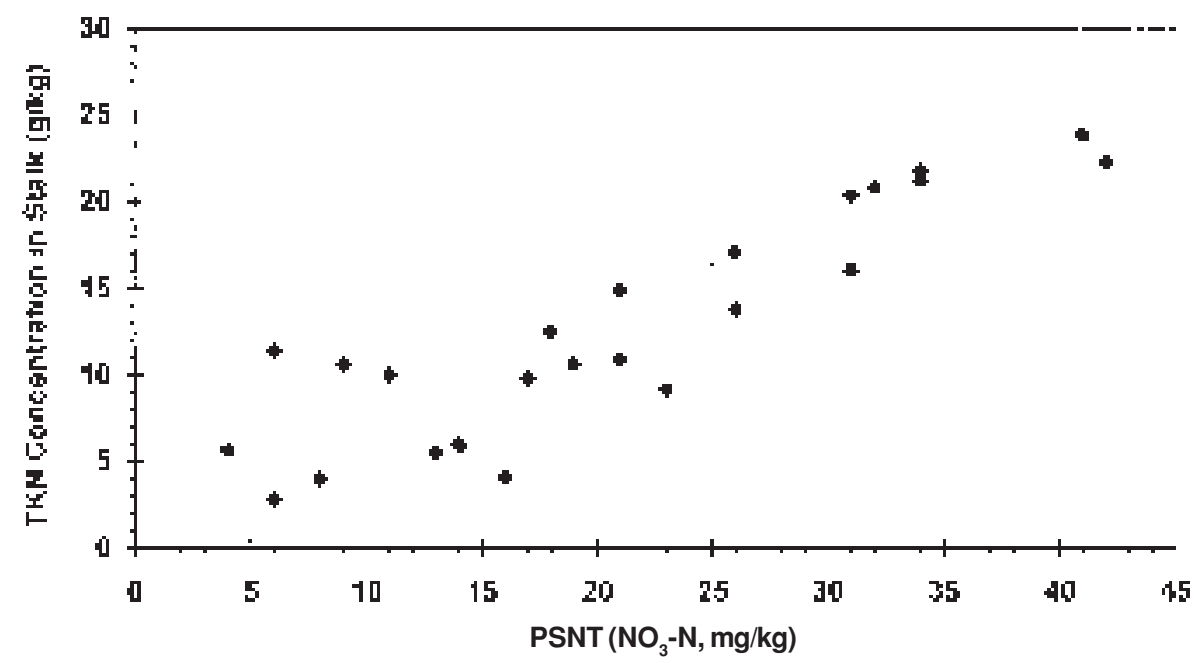

Fig. 3. Relationship between the presidedress soil nitrate test and the stalk total Kjeldahal N concentration of sweet corn at harvest.

Table 1. Concentrations of total Kjeldahl $\mathrm{N}$ and $\mathrm{NO}_{3}-\mathrm{N}$ in stalk samples collected from sweet corn cultivar trials at time of harvest, 19982000 .

\begin{tabular}{|c|c|c|}
\hline Cultivar & $\begin{array}{c}\text { Total } \\
\text { Kjeldahl N }\end{array}$ & $\mathrm{NO}_{3}-\mathrm{N}$ \\
\hline & \multicolumn{2}{|c|}{--------- g.kg ${ }^{-1} \ldots$} \\
\hline \multicolumn{3}{|c|}{1998} \\
\hline Calico Belle & 16.9 & 9.6 \\
\hline Brilliance Film Coat & 16.8 & 10.5 \\
\hline Sensor & 11.5 & 6.1 \\
\hline Silverado & 17.2 & 7.8 \\
\hline $\mathrm{LSD}_{0.05}$ & 1.5 & 1.2 \\
\hline \multicolumn{3}{|c|}{1999} \\
\hline Calico Belle & 18.8 & 10.6 \\
\hline Brilliance Film Coat & 20.7 & 12.9 \\
\hline Sensor & 13.7 & 7.1 \\
\hline Silverado & 20.9 & 10.0 \\
\hline $\mathrm{LSD}_{0.05}$ & 1.8 & 1.5 \\
\hline \multicolumn{3}{|c|}{2000} \\
\hline Calico Belle & 19.2 & 9.7 \\
\hline Brilliance Film Coat & 16.3 & 9.9 \\
\hline Sensor & 13.1 & 6.1 \\
\hline Silverado & 15.2 & 7.1 \\
\hline $\mathrm{LSD}_{0.05}$ & 2.7 & 1.0 \\
\hline \multicolumn{3}{|c|}{$P>\mathrm{F}$} \\
\hline Cultivar (C) & 0.0001 & 0.0001 \\
\hline Year (Y) & 0.0001 & 0.0001 \\
\hline $\mathrm{C} \times \mathrm{Y}$ & 0.01 & 0.16 \\
\hline
\end{tabular}

Table 2. Proposed Interpretations of the at-harvest stalk $\mathrm{N}$ test for sweet corn.

\begin{tabular}{crl}
\hline Total Kjeldahl $\mathrm{N}$ & \multicolumn{1}{c}{$\mathrm{NO}_{3}-\mathrm{N}$} & \multicolumn{1}{c}{ Interpretation } \\
\hline---11.0 & $<6.0$ & N-deficient, underfertilized \\
11.0 to 16.5 & 6.0 to 11.0 & Marginal, may be underfertilized \\
16.5 to 21.0 & 11.0 to 14.0 & Optimal range, $\mathrm{N}$ sufficient \\
$>21.0$ & $>14.0$ & Excessive, overfertilized \\
\hline
\end{tabular}

in subsequent growing seasons. Thus, on average, nearly twice as many growers currently using the Stalk TKN test would be encouraged to reduce $\mathrm{N}$ application rates as would be encouraged to increase $\mathrm{N}$ application. Just as the end-of-season stalk $\mathrm{N}$ test for field corn has been found to be a useful tool to improve $\mathrm{N}$ management (Binford et al., 1992; Fox et al., 2001; Hooker and Morris, 1999; Sims et al., 1995) we believe stalk testing for sweet corn, even with the uncertainty of the proposed interpretations, will provide information to help producers better manage $\mathrm{N}$.

\section{Literature Cited}

Binford, G.D., A.M. Blackmer, and N.M. El-Hout. 1990. Tissue test for excess nitrogen during corn production. Agron. J. 82:124-129. 
Binford, G.D., A.M. Blackmer, and B.G. Meese. 1992. Optimal concentrations of nitrate in cornstalks in maturity. Agron. J. 84:881-887.

Bremner, J.M. and C.S. Mulvaney. 1982. Nitrogen: Total, p. 595-624. In: A.L. Page et al. (ed.). Methods of soil analysis. Part 2. $2^{\text {nd }}$ ed. Agron. Monogr. 9. ASA and SSSA, Madison, Wis.

Cate, R.B., Jr., and L.A. Nelson. 1965. A rapid method for correlation of soil test analyses with plant response data. Tech. Bul. 1. Int. Soil Testing Ser. North Carolina State Univ., Raleigh.

Fox, R.H., W.P. Piekielek, and K.E. Macneal. 2001. Comparison of late-season diagnostic tests for predicting nitrogen status of corn. Agron. J. 93:590-597.

Fox, R.H., G.W. Roth, K.V. Iverson, and W.P. Piekielek. 1989. Soil and tissue nitrate test com- pared for predicting soil nitrogen availability to corn. Agron. J. 81:971-974.

Hanway, J.J. and A.L. Englehorn. 1958. Nitrate accumulation in some Iowa crop plants. Agron. J. 50:331-334

Hartz, T.K., W.E. Bendixen, and L. Wierdsma. 2000. The value of pre-sidedress soil nitrate testing as a nitrogen management tool in irrigated vegetable production. HortScience 35:651-656.

Heckman, J.R., W.T. Hlubick, D.J. Prostak, and J.W. Paterson. 1995. Pre-sidedress soil nitrate test for sweet corn. HortScience 30:1033-1036.

Heckman, J.R., T.F. Morris, J.T. Sims, J.B. Sieczka, U. Krogman, P. Nitzsche, and R. Ashley. 2002. Pre-sidedress soil nitrate test is effective for fall cabbage. HortScience 37:113-117.

Hooker, B.A. and T.F. Morris. 1999. End-of-season corn stalk test for excess nitrogen in silage corn. J. Prod. Agr., Vol. 12, No. 2.

Iversen, K.V., R.H. Fox, and W.P. Piekielek. 1985. Diurnal, shade, and hybrid effects on nitrate content of young corn stalks. Commun. Soil Sci. Plant Anal. 16:837-852.

Karlen, D.L., R.L. Flannery, and E.J. Sadler. 1988. Aerial accumulation and partitioning of nutrients by corn. Agron. J. 80:232-242.

Magdoff, F.R. 1991. Understanding the Magdoff pre-sidedress nitrate test for corn. J. Prod. Agr. 4:297-305.

Sims, Thomas J., Bruce L. Vasilas, Karen L. Gartley, Bill Milliken, and V. Green. 1995. Evaluation of soil and plant nitrogen tests for maize on manured soils of the Atlantic coastal plain. Agron J. 87:213-222. 